\title{
Synergy of Higher Education Collaboration with Local Governments in Efforts to Overcome the COVID-19 Pandemic
}

\author{
Karomani \\ Department of Communication Studies, \\ Faculty of Social and Political Sciences, \\ Universitas Lampung, Indonesia

\section{Mahpul} \\ Department of Language Education and Arts, \\ Faculty of Teacher Training and Education, \\ Universitas Lampung, Indonesia

\section{Iwan Satriawan} \\ Department of Law, Faculty of Law, \\ Universitas Lampung, Indonesia
}

DOI: https://doi.org/10.36941/ajis-2021-0054

\begin{abstract}
The COVID-19 pandemic has had a serious impact on various aspects of Indonesia, especially the economy. The government has made countermeasures by issuing various policies and social programs. However, the implementation of policies is not necessarily followed by the attitude of the people who are not disciplined and indifferent. The role of higher education is very much needed to provide guidance with a humanist approach. Therefore, it is necessary to have a synergy of good cooperation between local governments and universities in facing obstacles in overcoming the COVID-19 pandemic. The research aims to analyze how the synergy between the government and universities is in overcoming the COVID-19 pandemic cases in the community. The research was conducted with a qualitative approach. The data were obtained through literature review and interviews with the Provincial Government of Lampung and the University of Lampung. The results of the study show that the synergy between the government and universities is good. This is shown by interaction and mutual support. Where the government acts as a policy maker and facilitator, while universities act as a support for implementation through community service programs.
\end{abstract}

Keywords: The COVID-19 Pandemic, Public Policy Analysis, Synergy, Higher Education

\section{Introduction}

The condition of Indonesia and even the world is currently in a state of crisis (Phan, Nguyen, and Al, 2020). This condition is caused by the spread of the corona virus and has become a global pandemic (Phan, Nguyen, \& Al, 2020; Ulya, 2020). Data on September 10, 2020 on the website of the Task Force 
for the Acceleration of Handling COVID-19 in Indonesia, there were 207,203 positive positive cases in Indonesia, the number of patients who died was 8,456 people, the number of patients who had recovered was 147,510 , and the rest 51,237 were in the process of being treated. or be treated. Of course, this data shows that the number of cases is not small, even the cases continue to increase significantly.

The impact of the corona virus pandemic is extraordinary for almost all countries in the world. Almost all sectors are hampered by this pandemic. One of the sectors most affected by this pandemic is the economic sector (Burhanuddin and Abdi, 2020). Industrial activity and market activity have become very slow, causing companies to adopt policies to cut employee salaries, and even lay off employees to minimize expenses (Ulya, 2020; Omonijo and Anyaegbunam, 2020). Of course, this can reduce people's purchasing power.

To deal with the spread of this virus, the Indonesian government has implemented various policies. The policy is carried out comprehensively in coordination with local governments. The number of local government policies, especially the Lampung Provincial Government, which are implemented is not necessarily accompanied by community compliance and discipline (BAPPEDA Lampung Province, 2020). Even the simplest policies on health protocols are widely violated. The author's initial survey of the public regarding matters related to the spread of the corona virus shows quite surprising data. As many as $70 \%$ of respondents said they were not afraid and did not believe this virus existed. They even said that the government had exaggerated the problem. Of course, this makes sense because it relates to their very low level of knowledge about viruses. So, they seem to underestimate the problem of spreading this virus. This condition will indirectly hinder the government's steps in restoring the economy because the spread of the virus will be increasingly difficult to stop. Therefore, we need other institutions that are more capable of taking a humanist approach to society, one of which is universities.

Higher education has a vital role in dealing with the spread of this virus. Higher education generally takes a humanist approach by carrying out various educational activities. This method is considered to have good effectiveness because it emphasizes increasing public awareness, not in the form of coercion. Therefore, the government needs to build harmonious cooperation with universities.

There are several universities in Lampung Province, one of which is Lampung University. Collaboration between the Regional Government of Lampung Province and the University of Lampung has been going on for a long time in various fields, especially in sustainable development which has a mission to improve the socio-economic community in Lampung. So that cases of poverty and hunger can be reduced. The existence of this corona virus pandemic problem certainly hinders the continuation of this collaboration. The reason is, disruption of economic activity due to the pandemic will increase poverty and hunger in the community. Therefore, this research was conducted to see how the sustainable development synergy model of the Regional Government of Lampung Province and Lampung University in overcoming the corona virus pandemic.

\section{Review Literature}

\subsection{Coronavirus}

Coronavirus is a type of virus that comes from the Orthocronavirinae subfamily in the Coronaviridae family and the order Nidovirales (Yunus and Rezki, 2020). Coronavirus is a virus that can cause respiratory infections such as Middle East Respiratory Syndrome (MERS) and Severe Acute Respiratory Syndrome (SARS) (Budiansyah, 2020; Ulya, 2020; Yunus and Rezki, 2020). This virus was first announced to the world community on December 1, 2019 in China, to be precise in the Wuhan area of Hubei Province, China. This virus continues to spread rapidly without control because there is no suitable drug (Whitworth, 2020). For those who have congenital health problems in their bodies such as diabetes, chronic respiratory disease, and cancer, they will be more at risk for more serious impacts (Ulya, 2020). The COVID-19 virus can spread through saliva droplets and fluids from the nose when an infected person coughs or sneezes. 


\subsection{The Impact of the COVID-19 Pandemic in Indonesia}

The impact of this corona virus pandemic is extraordinary. Almost all activities in various sectors have been hampered by this pandemic, especially when large-scale social restriction policies were implemented. The economic sector is one of the most affected (Burhanuddin and Abdi, 2020). Even though this sector is related to the lives of many people. Industrial activity and market activity have become very slow. Slow economic activity causes companies to cut employee salaries, and even lay off employees to minimize expenses (Ulya, 2020; Omonijo and Anyaegbunam, 2020). Of course, this can reduce people's purchasing power. Daily workers, such as restaurant workers or public transportation service providers, also cannot carry out activities at all. Other problems also arise such as the limited budget for handling COVID-19, the unavailability of adequate facilities and infrastructure, the unpreparedness of medical personnel in dealing with COVID-19, and a lack of medical personnel (Ulya, 2020).

\subsection{Indonesian Government Policy in Facing the COVID-19 Pandemic}

To deal with the spread of this virus, the Indonesian government has implemented various policies. The policy is carried out comprehensively in coordination with local governments. There are six policies in place to respond to COVID-19, namely 1 ) ensuring that budget refocusing is carried out quickly in accordance with the supporting regulations, technical and institutional guidelines that have been established; 2) implementation of the health budget quickly and precisely, especially for purchasing medical devices, protecting health personnel and increasing the capacity of referral hospitals. As the front guard in handling COVID-19; 3) ensure that the most vulnerable economic groups have the ability to meet their daily needs, and accelerate the realization of social assistance programs such as the Family Hope Program, Non-Cash Food Assistance, Pre-Work Cards, subsidies and implementation of postponement of community credit / debt installments; 4) guarantee of operational continuity and business incentives, especially in badly affected sectors, such as transportation, trade, accommodation / restaurants (tourism), and labor-intensive industries which experienced a sharp decline in turnover; 5) synergy and harmonization of policies between the central, provincial and district / city governments in restructuring expenditures and development budgets so that efforts to combat COVID-19 run productively and optimally and are right on target; and 6) maintaining economic stability and continuing to build public confidence in economic performance through policy analysis and evaluation of the impact of COVID-19 on the economy from time to time, as well as taking further policy coordination steps to safeguard macroeconomics and the financial system. stability to sustain growth. the economy remains good and resilient (BAPPEDA Lampung Province, 2020). In addition, the policy of implementing health protocols was carried out to break the chain of spreading the corona virus.

\subsection{The Synergy of Local Government and Higher Education in Facing Pandemic}

Higher education has an important role in dealing with pandemic problems that occur. Especially in terms of direct guidance to the community. There needs to be harmony between local governments and universities in an effort to overcome this pandemic (Mustafa, Berani, Berisha, 2019). This is because the local government is less effective in providing guidance to the community with the policies issued. There is a need for a humanist approach to the community in providing guidance so that their knowledge and awareness of this problem can increase (Widhyharto, Pertiwiningrum, and Sutopo, 2013). This is where a synergy of cooperation between local governments and universities is needed. Especially with the sustainable development synergy program between Higher Education and Local Government where the main objective is to improve the economy and alleviate poverty. 


\section{Methodology}

This type of research is qualitative research. Qualitative research is empirical research where data is not in the form of numbers. Qualitative research has the characteristics of constructing reality and understanding its meaning so that it usually pays close attention to processes, events and authenticity (Somantri, 2005; Sugiyono, 2012). Qualitative research characteristics will be very helpful in finding and understanding research questions. Among these characteristics, researchers can use multiple methods that are interactive and humanistic.

This study uses a qualitative approach as a means of uncovering research problems. The focus of attention is directed at the model of sustainable development cooperation between the University of Lampung and the Regional Government of Lampung Province. The strength of this research is the position of the researcher as a participant-observer, namely as the secretary of the SDGs at the University of Lampung so that it can produce a more authentic reflection on the phenomenon of the problem being studied.

Data analysis was carried out by collaborative integrative analysis which refers to the following three steps, 1) description, an effort to explain the current conditions (existing conditions) related to the dynamics of institutional structures, institutional settings and involvement of actors. It is important to do this to provide an initial portrait of the conditions for cooperation. 2) tendencies, efforts to identify trends that arise from various collaborations. This is done by affirming and highlighting important issues related to cooperation. 3) interpretation, an effort to justify portraits and trends that occur in the implementation of cooperation. In this third stage, the researcher tries to combine institutional theory with field facts, so that a comprehensive analysis of the collaboration process will be obtained (Widhyharto, Pertiwiningrum, and Sutopo, 2013).

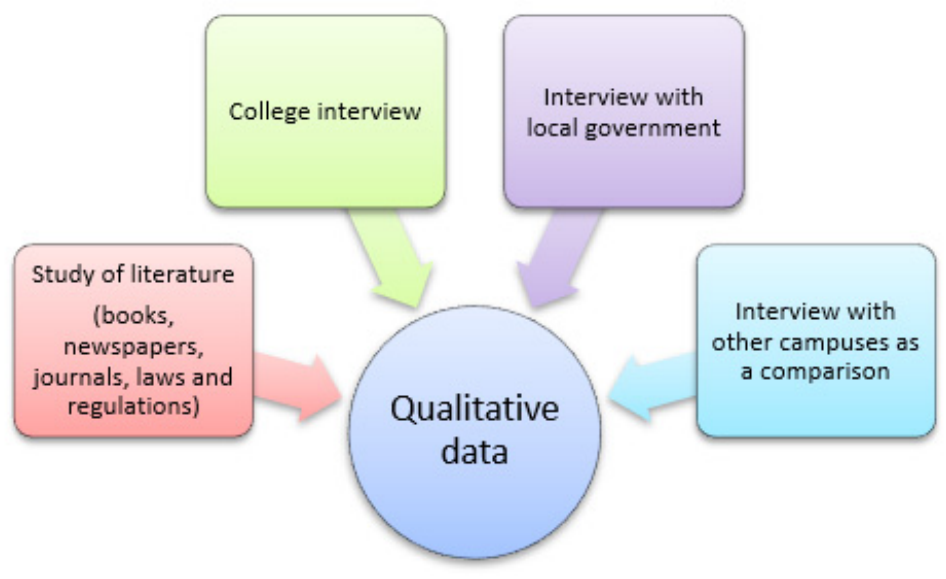

Figure 1: Steps Taken in Research

In order to obtain the necessary data, this research was conducted in two ways, namely through literature studies and analysis of sustainable development cooperation models between tertiary institutions and local governments. Literature study is carried out by tracing written sources, both media reports and various opinions. Meanwhile, the analysis of the cooperation model was carried out through an interview process with the parties involved, both from the University of Lampung and the regional government of Lampung Province. In order to obtain more in-depth and complete information, a comparison of cooperation models was also carried out with other universities.

The collected data will be selected on the basis of the contribution of each data to the research variables that have been determined previously. Data from in-depth interviews and literature search 
data have an equally important position as data sources in this study. Therefore, the two data will complement and control one another. The results of the analysis of the two data were given an analysis related to patterns or models of sustainable cooperation between universities and local governments related to the Covid-19 pandemic response.

\section{Results \& Discussion}

\subsection{Impact of the Corona Virus Pandemic (COVID-19)}

The emergence of the COVID-19 pandemic has had an impact on various aspects of the life of the Indonesian people, even the world. Some of the impacts that arise are broadly related to livelihoods, causing food insecurity, frequent migration, the implementation of many government social programs, new knowledge and health behaviors, and increased crime rates (Kurniawansyah, et al., 2020).

In connection with community work activities, the emergence of COVID-19 requires people to always maintain a safe distance. This is implemented through the implementation of large-scale social restriction policies, a work from home system, and semi-lockdowns. Such a system cannot provide maximum results, especially for production activities. In addition, the number of people's purchases of products is much reduced because they are more active at home. So that the company's income is drastically reduced. This can lead to layoffs in large numbers by companies to reduce spending. The existence of a large number of layoffs will result in an increase in unemployment and poverty in Indonesia.

The increase in unemployment during the pandemic has caused people's purchasing power to decrease and the production process has also stopped. This will lead to food insecurity. To avoid this, people with sufficient financial capacity also over-purchase basic commodities as stock when the lockdown is implemented. This phenomenon also triggers food insecurity, thereby increasing the risk of an increase in the number of hunger cases.

The implementation of large-scale social restriction policies also resulted in the cessation of work activities. The absence of jobs and the high cost of living in the affected areas lead to increased migration. The migration process is dominated by moving from cities to villages. The data also show that during the pandemic and ahead of the implementation of large-scale social restriction policies, the adoption of migration from cities to villages increased by $38 \%$ for men and $31 \%$ for women. People who migrate are generally those with uncertain livelihoods, such as selling, construction workers, and so on. Of course, indirectly this will also increase the risk of spreading COVID-19 from urban to rural areas.

In order to cope with the effects of a pandemic, the government immediately took strategic steps by implementing various social programs. The government budget is more focused on helping ease the burden on society. The social programs implemented include the Family Hope Program, Non-Cash Food Assistance, Pre-Work Cards, subsidies and implementation of postponement of credit / community debt installments.

The increase in unemployment and poverty rates creates another problem, namely an increase in the crime rate. This is due to the increasing pressure and pressure on the necessities of life, but the people's purchasing power is decreasing. In addition, government policies to reduce the number of prisoners in the context of social distancing efforts also exacerbate conditions. This is shown by data in April 2020, where the crime rate increased by $19.72 \%$.

Apart from the negative impacts, positive impacts have also begun to appear, especially in terms of public health knowledge and behavior. This is inseparable from the fast spread of digital information received by the public, especially those related to the corona virus and its prevention. Of course, this affects people's behavior in terms of improved hygiene habits and exercise.

Of all the impacts, the most felt during the COVID-19 pandemic was in the economic sector (Burhanuddin and Abdi, 2020). The existence of an incorrect prediction from the Indonesian government about the pandemic economy has had a tremendous impact where sellers, buyers and producers will prefer to stay at home, even being forced to stay at home. This results in minimal meeting activity between sellers and buyers so that economic activity becomes abnormal. In addition, the lack of production activity 
as a result of the work from home policy has resulted in limited products in the field, thus risking inflation. Of course, this condition will be very dangerous to Indonesia's economic condition.

\subsection{Local Government Policies in Handling the Spread of COVID-19}

Basically, the government will not be able to avoid the death rate and the economic impact of the spread of this corona virus (Anderson et al., 2020). However, the government still has an obligation to protect its citizens so that it must maximize all efforts to protect its people who have been devastated by the COVID-19 outbreak (Kurniawansyah, et al., 2020; Greenleaf, 1996; Pramono and Raharjo, 2020). This is shown through the various policies issued. Viewed from the aspect of the institutional model, the government should have the main task of making policies or in other terms called public policy producers. Public policy is an authority that is owned and implemented by the government (Parsons, 2011; Torgerson, 2017).

Several policies have been issued by the Indonesian government in dealing with this pandemic. The initial policy when the COVID-19 case had not been detected in Indonesia was to increase tourism promotion by taking advantage of the increasing cases in China, Japan and Korea. In other words, the government is targeting tourists who have canceled their trips to the three countries and open access as wide as possible where other countries have started to restrict access. Making this policy seems to show that the government has economic developmentalist reasoning in preparation for the spread of COVID-19 (Almuttaqi, 2020). However, this turned out to be the government's blunder in reading the situation and ultimately determining policies.

When a COVID-19 case is detected and spreads in Indonesia, the government immediately changes the policies that have been implemented and establishes an emergency status for the COVID19 pandemic disaster. What is most visible is the diversion of the budget which is focused on handling the COVID-19 pandemic and helping to ease the burden on the community through social programs. Another policy is to implement large-scale social restrictions or in other words, it is called a semilockdown. The implementation of this policy was carried out to reduce the rate of virus transmission and maintain national economic stability. Other policies continue to be issued by the government, namely: a) providing free personal protective equipment (PPE) for COVID-19 referral hospitals; b) buying a COVID-19 test kit; c) issue an appeal to the community not to leave the area; d) urge the public to carry out social distancing, physical distancing, diligently wash their hands using soap, and campaign for the slogan "at home"; e) make a policy of dismissing educational institutions and a work from home policy; f) carry out a mass rapid test for COVID-19 and spray disinfectants in public places; g) check the health of people who travel outside the area and even go into isolation; and h) take various economic policies to maintain people's purchasing power. The application of social distancing is carried out for fourteen days and applies a minimum distance of two meters when interacting with other people according to the protocol (Wang, Hu, and et al, 2020; Walker, et al., 2020). The spread of the virus is suppressed by strategies to control the source of infection, protect susceptible people, and break the chain of human-to-human transmission (He, Deng, \& Li, 2020; Li, et al., 2020; Chan, et al, 2020). The application of social distancing is also carried out based on the characteristics of virus transmission that occurs through droplets when coughing or sneezing (Mijnes et al, 2004; Abidah \& et al, 2020; Hollingsworth, Klinkenberg, \& Anderson, 2011; Hellewell, Abbott, \& et al, 2020).

\section{$4 \cdot 3$ \\ Synergy between Local Government and Higher Education}

Higher education can play a role in supporting local government efforts in developing various sectors of regional development, especially the economic, social and cultural sectors (Mullakhmetov, Aminova, Filimonchuk, 2019). In this case, of course, taking into account the priority needs and superior potential of the region concerned. Local governments can play a role in supporting the development of higher education, especially higher education activities in the field of research and community service.

In creating synergy between tertiary institutions and local governments, it must be supported 
with the main prerequisite, namely sharing information, especially regarding COVID-19. In the information age, it is possible to develop various media so that both universities and local governments can provide complete, correct and transparent information as well as a form of public accountability. The local government is expected to be able to inform the priorities of handling the COVID-19 pandemic so that universities can respond positively according to their potential.

\section{Public}
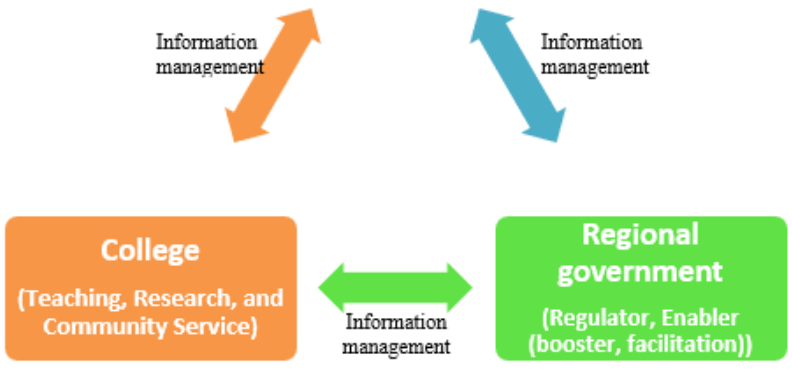

Figure 2. Implementation of Relations between Local Government, Higher Education and Community

In general, the description of the synergy model of local government, tertiary institutions, and the community can be described with a golden triangle (see Figure 2). A triangle is a shape formed with three points (Balai Pustaka, 2001; Fardiah, 2006; Widhyharto, Pertiwiningrum, and Sutopo, 2013). In this case it is the point of higher education, the point of local government and the point of society. Gold is a precious metal that usually has useful and beneficial values (Balai Pustaka, 20o1; Widhyharto, Pertiwiningrum, and Sutopo, 2013). Figure 2 is likened to an intertwined chain, each of which has benefits (use value) and is interdependent as a system. Meanwhile, the two-way arrow indicates a reciprocal interaction pattern.

Local governments as policy producers will implement public policies in the common interest (Taufiqurokhman, 2014; Kurniawansyah, et al., 2020). However, sometimes this implementation creates an inappropriate response. The source of the problem that often occurs is the delivery of inappropriate information. To support this, the role of universities is needed. In this case, universities can take a more humanist approach to provide guidance to the community on understanding policies (Widhyharto, Pertiwiningrum, and Sutopo, 2013). This approach is considered more acceptable to the community because it is carried out with a different approach. However, this does not necessarily guarantee that society as a whole will accept it.

As an illustration, policies on social distancing, physical distancing, and work from home are considered unsuccessful (Margianto, 2020). In fact, this appeal was not followed by the community. This happened because of the urgent necessities of life and the lack of knowledge and awareness related to COVID-19. In the midst of the COVID-19 pandemic in Indonesia, which shows more and more positive cases, it seems that people are not afraid and choose to take vacations, go to shopping centers, hold grand tablighs, and other activities carried out in groups. This is of course contrary to the government's appeal to carry out social distancing and stay at home. Of course, universities need to take their role by providing guidance through a humanist approach. So that the community is expected to be more aware and aware of the situation and conditions that occur. 
Referring to the golden triangle system, the University of Lampung as one of the tertiary institutions in the Lampung Province Regional Government also has an important role in handling COVID-19 in Lampung Province, Indonesia. To reduce the spread of COVID-19, the Lampung Provincial Government implemented a large-scale social restriction policy, requiring people to wear masks, urging people to stay at home, and maintain distance when interacting. Social programs are also carried out by preparing a budget in order to ease the burden on the affected community.

However, in fact, community discipline is a big problem. There are still many violations of policy implementation, such as not wearing masks while traveling, staying in public places, and so on. Of course this is a problem that needs to be overcome, because the subject of discipline is always related to the individual himself.

Lampung University plays its role in the golden triangle in dealing with these problems. By overcoming this problem, it will indirectly help the government in reducing the spread of COVID-19. The results of interviews with universities provided information that the University of Lampung had carried out coaching activities both offline and online to harmonize the views of the community with the government through a humanist approach. These activities are carried out in the context of community service. In addition, research related to COVID-19 is also being encouraged, both from social and scientific aspects. So that the information obtained can be used as a basis for policy making for the government to reduce the spread rate. On the other hand, the University of Lampung also implements government policies in the campus environment so that it can be used as an example for the community or other universities. To support the implementation of the University of Lampung program in conducting coaching and research, the Regional Government of Lampung Province and even the central government have prepared a budget as well as its facilities and infrastructure. This phenomenon is in accordance with the golden triangle cooperation model where reciprocal interactions occur (Balai Pustaka, 2001; (Widhyharto, Pertiwiningrum, and Sutopo, 2013)). With a system of cooperation like this, it is of course expected that handling of COVID-19 cases can be suppressed so that indirectly the economy will gradually improve and the poverty rate will decrease.

\section{Conclusion}

Based on the description above, it can be concluded that basically the government, especially the Lampung Provincial Government, has made various efforts to deal with the COVID-19 pandemic case. Various social policies and programs have been implemented. However, the problem of community discipline is a problem in itself. In this case, the University of Lampung takes its role to provide guidance and become a roll model in implementing government policies. The synergy of cooperation between the University of Lampung and the Provincial Government of Lampung is illustrated by the golden triangle model. Where the University of Lampung helps the government in implementing policies with different approaches, and the government supports the campus program by providing adequate facilities and infrastructure. This cooperation system needs to be continuously improved so that the handling of COVID-19 can be more effective so that the health and economic conditions of the community can quickly recover.

\section{References}

Abidah, A., \& dkk. (2020). The Impact of Covid 19 to Indonesian Education and Its Relation to the Philosophy of "Merdeka Belajar". Studies in Philosophy of Science and Education, 1(1), 38-49.

Almuttaqi, A. I. (2020). Kekacauan Respon terhadap Covid 19 di Indonesia. Jakarta: The Insights The Habibie Center. Anderson, R. M., et al. (2020). How will country-based mitigation measures influence the course of the Covid 19 epidemic? The Lancet 395 (10228), 931-934. 
Balai Pustaka. (2001). Kamus Besar Bahasa Indonesia, Edisi Ketiga, Departemen Pendidikan Nasional.

BAPPEDA Provinsi Lampung (2020). Enam Kebijakan Upaya Provinsi Lampung Dalam Mengantisipasi Dampak Ekonomi Covid-19, dapat diakses di http://bappeda.lampungprov.go.id/berita-enam-kebijakan-upayaprovinsi-lampung-dalam-mengantisipasi-dampak-ekonomi-covid19.html\#ixzz6XiGoDYvT

Budiansyah, A. (2020). Apa Itu Virus Corona dan Cirinya Menurut Situs WHO. Jakarta: CNBC Indonesia.

Burhanuddin, C. I. and Abdi M. N. (2020). Ancaman Krisis Ekonomi Global Dari Dampak Penyebaran Virus Corona (COVID-19). Akmen, 17(1), 90-98.

Chan, et al. (2020). A Familial Cluster of Pneumonia Associated with the 2019 Novel Coronavirus indicating person to person transmission: a studi of a family cluster. Lancet 395 (10223), 514-523.

Fardiah, D. (2006). Pola Relasi Perguruan Tinggi Dan Pemerintah Daerah Dalam Upaya Meningkatkan IPM Di Jawa Barat. Mimbar: Jurnal Sosial dan Pembangunan, 22(4), 444 - 464.

Greenleaf, R. K. (1996). On Becoming a Servant Leader. San frascisco: JosseyBas.

He F., Deng Y, and Li W. (2020) Coronavirus Disease 2019: What We Know?. Journal of Medical Virology, 92, 719725 .

Hellewell, J., Abbott, S., \& dkk. (2020). Feasibility of Controlling Covid 19 Outbreeaks by isolation of cases and contacts. Lancet Glob Health

Hollingsworth, T., Klinkenberg, D., \& Anderson, H. H. (2011). Mitigation strategies for pandemic influenza A: Balancing conflicting policy objectives. Plos Comput Biol 7 (e1001076).

Kurniawansyah H. et al. (2020). Konsep Kebijakan Strategis Dalam Menangani Eksternalitas Ekonomi Dari Covid19 Pada Masyarakat Rentan Di Indonesia. Indonesian Journal of Social Sciences and Humanities, 1(2), 130-139

$\mathrm{Li}$, et al. (2020). Coronavirus infections and immune responses. Journal of Medical Virology, 92, 424-432.

Li, Q. et al. (2020). Early Transmission Dynamics in Wuhan, China, of Novel Coronavirus Infected Pneumonia. $N$ Eng J Med.

Margianto, H. (2020, April 1). Pembatasan Sosial Berskala Besar, Efektifkah Lawan Corona. Dipetik April 8, 2020, dari Kompas.com: https://nasional.kompas.com/read/2020/o4/o1/11054741/pembatasan-sosialberskalabesar-efektifkah-lawan-corona

Mijnes, D. G., et al. (2004). Natural History of a Recurrent Felline Coronavirus Infection and The Role of Cellular Immunity in Survival and Discase. Journal of Virology 79 (2).

Mullakhmetov K.S., Aminova R.M., Filimonchuk I.I. (2019) Administrative Innovations as Necessary Condition of Competitiveness in Schools. Journal of Educational and Social Research, 9(4), $21-26$.

Mustafa S., Berani F., Berisha H. (2019). Managing Organizational Conflicts: A Study among Organizations in Kosovo. Journal of Educational and Social Research, 9(1), 29-35.

Omonijo, D. O. and Anyaegbunam, M.C. (2020). Exploring the Concept of Social Change in the Thought of Ibn Khaldun. Academic Journal of Interdisciplinary Studies, 9(5)

Parsons, W. (2011). Public Policy: Pengantar Teori dan Praktek Analisis Kebijakan. Jakarta: Kencana.

Phan, Nguyen, L., \& Al. (2020). Importation and Human-to-human transmissionof a Novel Coronavirus in Vietnam. NEng J med

Pramono J. and Raharjo F. S. (2020). Kebijakan Taktis Pemerintah Daerah Di Pulau Jawa Dalam Penanganan Corona Virus Disease (COVID-19). Jurnal Manajemen Publik \& Kebijakan Publik, 2(2).

Somantri, G. R. (2005). Memahami Metode Kualitatif. Makara, Sosial Humaniora, 9(2), 57 - 62.

Sugiyono (2012). Memahami Penelitian Kualitatif. Jakarta: Bumi Aksara.

Taufiqurokhman. (2014). Kebijakan Publik Pendelegasian Tanggungjawab Negara Kepada Presiden Selaku Penyelenggara Pemerintahan. Jakarta: Fisip Universitas Moestopo Beragama Pers.

Torgerson, D. (2017). Policy sciences and democracy: A reexamination. Policy Sciences, 5o(3), 339-350.

Ulya H. N. (2020). Alternatif Strategi Penanganan Dampak Ekonomi Covid-19 Pemerintah Daerah Jawa Timur Pada Kawasan Agropolitan. el Barka: Journal of Islamic Economic and Business, 3(1), 80 - 109.

Walker, G. T. P., et al. (2020). The Global Impact of COVID-19 and Strategies for Mitigation and Suppression. WHO Collaborating Centre for Infectious Disease Modelling, MRC Centre for Global Infectious Disease Analysis, Abdul Latif Jameel Institute for Disease and Emergency Analytics. London: Imperial College.

Wang, H. et al. (2020). Clinical Characteristic of 138 hospitalized parients with 2019 novel coronavirus-infected pneumonia in Wuhan, China. JAMA.

Whitworth, J. (2020). Covid 19: A Fast EvolvingPandemic. Trans R Soc Trop Med Hyg.

Widhyharto, Pertiwiningrum, dan Sutopo (2013) Model Kerjasama Lembaga Swasta, Pemerintah Dan Pendidikan Tinggi. Sosiologi Reflektif, 7(2).

Yunus, N.R. \& Rezki, A. (2020). Kebijakan Pemberlakuan Lockdown Sebagai Antisipasi Penyebaran Corona Virus Covid-19. SALAM (Jurnal Sosial E Budaya Syar-i), 7 (3), 227-238 